\title{
Hubungan Pengetahuan dan Tindakan Menjaga Kesehatan Gigi Mulut dengan Keluhan Subyektif Permasalahan Gigi Mulut pada Mahasiswa Kesehatan dan Non Kesehatan
}

\author{
Tira H. Skripsa, ${ }^{*}$ Audrey A. Unique, ${ }^{1 *}$ Donna Hermawati ${ }^{2}$
}

\author{
${ }^{1}$ Departemen Kedokteran Gigi Fakultas Kedokteran Universitas Diponegoro, Semarang, \\ Jawa Tengah, Indonesia \\ ${ }^{2}$ Departemen Kedokteran Fakultas Kedokteran, Universitas Diponegoro, Semarang, Jawa \\ Tengah, Indonesia \\ *Kedua Penulis memiliki kontribusi yang sama dalam penulisan naskah. \\ Email: tirahamdillahskripsa@ lecturer.undip.ac.id
}

\begin{abstract}
Individual behavior related to oral health could cause poor oral condition. Health behavior consists of domains of knowledge, attitude, and action related to health, including oral health. This study was aimed to evaluate the relationship between knowledge and action to maintain oral health and subjective complaints related to oral condition of medical and non-medical students. This was an analytical and observational study with a cross sectional design. Samples were medical and nonmedical students obtained by using the consecutive sampling technique. Data were collected at Diponegoro University using online questionnaire through the Google form platform regarding knowledge, actions to maintain oral health, and subjective complaints of oral health problems. Data were analyzed by using the chi-square test. The results showed that the majority of students had a high level of knowledge about dental and oral health, meanwhile, their action to maintain oral health was in moderate level. The levels of knowledge and action to maintain oral health of medical students were better than of the non-medical students. Dental and oral health problems most frequently complained were recurrent aphtous ulcers (RAU) and dental caries. The chi-square test showed a p-value of 0.023 between the action to maintain oral health and subjective complaints of oral health problems. In conclusion, there was a significant relationship between the action to maintain oral health and subjective complaints of oral health problems.
\end{abstract}

Keywords: knowledge, action to maintain oral health, dental and oral health problem

\begin{abstract}
Abstrak: Salah satu faktor penyebab permasalahan gigi dan mulut ialah perilaku terkait kesehatan gigi dan mulut. Perilaku kesehatan terdiri dari domain pengetahuan, sikap, dan tindakan yang berkait-an dengan kesehatan termasuk kesehatan gigi dan mulut. Penelitian ini bertujuan untuk mengetahui hubungan pengetahuan dan tindakan menjaga kesehatan gigi dan mulut dengan keluhan subyektif permasalahan gigi dan mulut pada mahasiswa kesehatan dan non kesehatan. Jenis penelitian ialah observasional analitik dengan desain potong lintang. Sampel penelitian ialah mahasiswa kesehatan dan non kesehatan, diperoleh dengan teknik consecutive sampling. Pengambilan data dilakukan di Universitas Diponegoro dengan menggunakan kuesioner online melalui platform Google form ten-tang pengetahuan, tindakan menjaga kesehatan gigi dan mulut, dan keluhan subyektif permasalahan kesehatan gigi dan mulut. Analisis statistik menggunakan uji chi-square. Hasil penelitian menunjukkan tingkat pengetahuan kesehatan gigi dan mulut mahasiswa umumnya tinggi, sedangkan tindakan menjaga kesehatan gigi dan mulut umumnya berada pada kategori sedang. Tingkat pengetahuan dan tindakan menjaga kesehatan gigi dan mulut mahasiswa kesehatan lebih baik daripada yang non kesehatan. Permasalahan yang terbanyak dikeluhkan ialah recurrent aphtous ulcers (RAU) dan karies gigi. Uji chi-square mendapatkan nilai $\mathrm{p}=0,023$ untuk hubungan tindakan menjaga kesehatan gigi dan mulut dengan keluhan subyektif permasalahan kesehatan gigi dan mulut. Simpulan penelitian ini ialah terdapat hubungan bermakna antara tindakan menjaga kesehatan gigi dan mulut dengan keluhan subyektif permasalahan kesehatan gigi dan mulut.
\end{abstract}

Kata kunci: pengetahuan, tindakan menjaga kesehatan gigi dan mulut, masalah kesehatan gigi mulut 


\section{PENDAHULUAN}

Kesehatan gigi dan mulut merupakan faktor integral kesehatan dan kesejahteraan tubuh secara keseluruhan yang tidak dapat dipisahkan antara satu dengan yang lainnya. ${ }^{1}$ Rongga mulut terdiri dari gigi, gingiva, saliva, lidah, dan pipi yang merupakan satu unit fungsional saling bergantung dan berkaitan dengan fungsi pengunyahan, bicara, bernapas, dan psikologis (meningkatkan rasa percaya diri). ${ }^{1,2}$ Namun, sebagian besar masyarakat masih kurang menyadari, menganggap remeh, serta bersikap kurang peduli terhadap kebersihan dan kesehatan gigi dan mulut. ${ }^{3}$

Salah satu permasalahan kesehatan gigi dan mulut yang paling umum dijumpai pada semua kelompok usia saat ini ialah kondisi rongga mulut yang buruk. Berdasarkan hasil Riset Kesehatan Dasar (Riskesdas) Nasional tahun 2018, angka permasalahan gigi dan mulut di Indonesia mencapai 57,6\%. Provinsi Jawa Tengah menunjukkan proporsi permasalahan gigi dan mulut mencapai $56,7 \%$. Proporsi permasalahan gigi dengan persentase tertinggi di Indonesia ialah gigi rusak/ berlubang/sakit yang mencapai $45,3 \%$. Proporsi permasalahan kesehatan mulut tertinggi yang dialami mayoritas penduduk Indonesia ialah gusi bengkak dan/atau keluar bisul (abses) sebesar 14\%."

Faktor-faktor yang dapat menyebabkan terjadinya permasalahan gigi dan mulut terdiri dari faktor internal dan eksternal. Pada permasalahan karies gigi, faktor internal meliputi pejamu (gigi dan saliva), mikroorganisme atau plak, substrat makanan, dan waktu. Sebaliknya, faktor eksternal antara lain ialah: jenis kelamin, usia, suku bangsa, kondisi sosial ekonomi, letak geografis, kesadaran, sikap, dan perilaku individu terkait kesehatan gigi dan mulut. ${ }^{5}$

Perilaku kesehatan (termasuk kesehatan gigi dan mulut) dapat dibagi menjadi pengetahuan, sikap dan tindakan. Pengetahuan yang dimiliki oleh masing-masing individu dapat membentuk sikap dan tindakan individu tersebut dalam kehidupannya sehari-hari. ${ }^{6}$ Perilaku menjaga kesehatan gigi dan mulut yang dilandasi pengetahuan, kesadaran dan sikap positif cenderung akan lebih memberi dampak yang nyata daripada yang tanpa dilandasi hal-hal tersebut. ${ }^{7}$ Sebaliknya, pengetahuan kesehatan gigi dan mulut yang kurang merupakan faktor predisposisi yang mengarah ke timbulnya permasalahan atau penyakit. $^{8}$

Penelitian ini dilakukan terhadap mahasiswa Universitas Diponegoro (Undip) yang merupakan salah satu perguruan tinggi negeri di Kota Semarang dengan karakteristik mahasiswa yang beragam. Berdasarkan latar belakang yang telah diuraikan, maka penulis tertarik untuk mengetahui hubungan antara pengetahuan dan tindakan menjaga kesehatan gigi dan mulut dengan keluhan subyektif permasalahan gigi dan mulut mahasiswa Undip. Hasil penelitian ini diharapkan dapat menjadi informasi tambahan mengenai gambaran pengetahuan, tindakan menjaga kesehatan gigi dan mulut, dan keluhan permasalahan terkait kesehatan gigi dan mulut sebagai pertimbangan dalam perencanaan usaha promotif dan preventif terutama pada kelompok mahasiswa yang merupakan perwakilan populasi penting di masyarakat, serta menjadi sumber informasi bagi penelitian selanjutnya.

\section{METODE PENELITIAN}

Penelitian ini dilakukan pada bulan Oktober-November 2020. Jenis penelitian ialah observasional analitik dengan desain potong lintang. Jenis data pada penelitian ini ialah data primer dan pengambilan sampel dilakukan dengan teknik consecutive sampling. Populasi penelitian ialah mahasiswa Universitas Diponegoro yang memenuhi kriteria inklusi, yakni mahasiswa kesehatan dan non kesehatan angkatan 2016-2019 yang masih aktif mengikuti perkuliahan dan bersedia menjadi subjek dalam penelitian. Besar sampel diperoleh menggunakan rumus Lemeshow dan didapatkan hasil sebanyak 211 sampel pada masing-masing kelompok, sehingga jumlah sampel minimal keseluruhan yang dibutuhkan ialah 422 sampel.

Variabel yang diteliti dalam penelitian ini ialah pengetahuan, tindakan menjaga kesehatan gigi dan mulut, dan keluhan subyektif permasalahan terkait kesehatan 
gigi dan mulut. Pengambilan data dilakukan secara online dengan menggunakan kuesioner pada platform Google form yang telah dilakukan uji validitas dan reliabilitas. Hasil uji validitas pada 18 pertanyaan tindakan menjaga kesehatan gigi dan mulut memperoleh jumlah item pertanyaan yang valid sebanyak 14 pertanyaan. Kuesioner pengetahuan (Knowledge/K) berisi 14 pertanyaan mengenai pengetahuan kesehatan gigi dan mulut yang dinilai dari lima aspek dan kuesioner tindakan menjaga kesehatan gigi dan mulut (tindakan menjaga kesehatan gigi dan mulut/B) berisi 14 pertanyaan yang dinilai dari tiga aspek. Kategori tingkat pengetahuan dibagi menjadi: tinggi (10-14), sedang (5-9), dan rendah (0-4); kategori tindakan menjaga kesehatan gigi dan mulut dibagi menjadi: baik (42-56), sedang (2841), dan buruk (14-27); sedangkan kategori keluhan dibagi menjadi bermasalah dan tidak bermasalah.

Seluruh mahasiswa yang memenuhi kriteria inklusi dan bersedia menjadi responden penelitian diberikan informed consent dan mengisi pilihan bersedia pada laman awal Google form. Pengumpulan data kuesioner online dilakukan hingga jumlah sampel minimal terpenuhi. Data hasil penelitian kemudian diolah menggunakan software SPSS dan dilakukan analisis statistik inferensial dengan menggunakan uji chisquare untuk melakukan uji korelasi antara pengetahuan dan tindakan menjaga kesehatan gigi dan mulut kesehatan gigi dan mulut dengan keluhan subyektif permasalahan gigi dan mulut.

Penelitian ini telah mendapatkan izin penelitian dan ethical clearance dari Komisi Etik Penelitian Kesehatan (KEPK) Fakultas Kedokteran Universitas Diponegoro dengan nomor 234/EC/KEPK/FK-UNDIP/X/2020.

\section{HASIL PENELITIAN}

Tabel 1 memperlihatkan karakteristik responden penelitian berdasarkan angkatan dan jenis kelamin. Mayoritas responden berdasarkan angkatan merupakan mahasiswa angkatan 2017. Berdasarkan jenis kelamin, distribusi responden lebih dominan pada wanita, yaitu sebanyak 335 orang $(77,9 \%)$.
Gambar 1 memperlihatkan hasil penilaian kuesioner mengenai pengetahuan kesehatan gigi dan mulut mahasiswa. Hasil tingkat pengetahuan mahasiswa kesehatan dan non kesehatan tentang kesehatan gigi dan mulut mayoritas tinggi, tidak ada responden yang berada pada kategori tingkat pengetahuan rendah. Sebanyak 95,6\% responden berada pada kategori tinggi dengan persentase mahasiswa kesehatan $(49,3 \%)$ sedikit lebih tinggi daripada mahasiswa non kesehatan $(46,3 \%)$. Berdasarkan hasil jawaban responden terhadap kuesioner pengetahuan kesehatan gigi dan mulut, pertanyaan dengan jawaban salah terbanyak ialah pertanyaan mengenai cara menjaga kebersihan gigi dan mulut, terutama tentang cara membersihkan lidah. Sebanyak 113 responden $(26,3 \%)$ menjawab cara pembersihan lidah yang direkomendasikan ialah dengan menggunakan bulu sikat gigi.

Gambar 2 memperlihatkan hasil penilaian kuesioner mengenai tindakan menjaga kesehatan gigi dan mulut mahasiswa. Sebagian besar responden baik mahasiswa kesehatan maupun non kesehatan melakukan tindakan menjaga kesehatan gigi dan mulut dalam kategori sedang. Sebanyak 69,3\% responden berada pada kategori sedang dengan persentase mahasiswa non kesehatan $(41,4 \%)$ lebih tinggi daripada mahasiswa kesehatan $(27,9 \%)$. Pada kategori baik, persentase responden terbanyak ialah kelompok mahasiswa kesehatan dengan jumlah 93 responden $(21,6 \%)$ dan mahasiswa non kesehatan berjumlah 33 responden $(7,7 \%)$.

Berdasarkan jawaban responden terhadap kuesioner dapat diketahui bahwa 54 responden $(12,6 \%)$ tidak pernah berkunjung ke dokter gigi dan mayoritas responden belum melakukan pemeriksaan ke dokter gigi secara teratur. Jumlah responden yang melakukan pemeriksaan gigi ke dokter gigi secara rutin masih sedikit, hanya 66 orang $(15,3 \%)$ yang berkunjung ke dokter gigi kurang dari 6 bulan sekali. Selain itu, penggunaan dental floss pada responden penelitian ini juga masih minim. Terdapat sebanyak 282 responden 65,6\%) menjawab tidak pernah menggunakan dental floss. 
Tabel 1. Karakteristik responden berdasarkan jenis kelamin dan angkatan

\begin{tabular}{ccccccc}
\hline Mahasiswa & Jenis Kelamin & \multicolumn{4}{c}{ Angkatan } & Total \\
& & $\mathbf{2 0 1 6}$ & $\mathbf{2 0 1 7}$ & $\mathbf{2 0 1 8}$ & $\mathbf{2 0 1 9}$ & \\
\hline Kesehatan & Pria & 1 & 18 & 14 & 2 & 35 \\
& Wanita & 7 & 112 & 37 & 24 & 180 \\
\multirow{3}{*}{ Non Kesehatan } & Total & 8 & 130 & 51 & 26 & 215 \\
& Pria & 1 & 41 & 66 & 3 & 60 \\
& Wanita & 2 & 70 & 15 & 17 & 155 \\
& Total & 3 & 111 & 81 & 20 & 215 \\
\hline
\end{tabular}

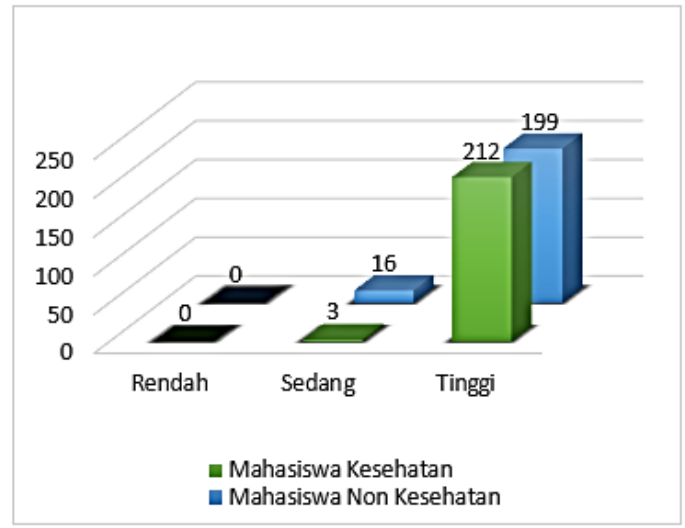

Gambar 1. Grafik tingkat pengetahuan kesehatan gigi dan mulut mahasiswa Universitas Diponegoro

Tabel 2 dan 3 memperlihatkan keluhan permasalahan kesehatan gigi dan mulut responden penelitian. Permasalahan yang paling banyak dikeluhkan responden ialah lesi mulut sariawan berulang (reccurent aphtous ulcer/RAU) yaitu pada total 53,4\% responden $(\mathrm{n}=382)$ serta dental karies pada $42,1 \%$ responden. Keluhan permasalahan selanjutnya yang paling banyak dirasakan ialah gigi sensitif atau hipersensitif dentin (25,9\%), bau mulut atau halitosis $(24,9 \%)$, gingivitis $(19,1 \%)$, dental stain (18\%),

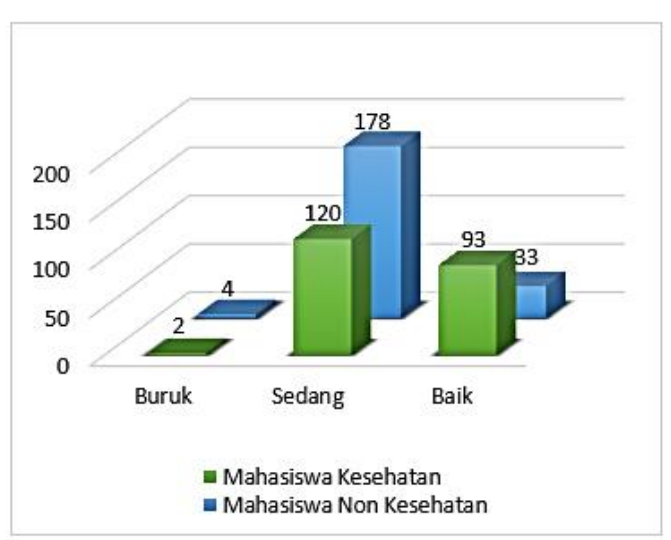

Gambar 2. Grafik tindakan menjaga kesehatan gigi dan mulut mahasiswa Universitas Diponegoro

keluhan gigi M3 (7,3\%), kalkulus dental $(5,8 \%)$, dan keluhan lainnya $(3,1 \%)$. Keluhan gigi dan mulut lain yang dipermasalahkan responden pada penelitian ini di antaranya ialah permasalahan temporomandibular disorder (TMD), gusi mudah berdarah, polip pulpa, gigi goyang, dan batu tonsil. Permasalahan estetik seperti keinginan pasien mengoreksi susunan gigi yang tidak teratur, memutihkan gigi, dan permasalahan terkait perawatan ortodonti tidak dimasukkan pada penelitian ini.

Tabel 2. Distribusi mahasiswa berdasarkan keluhan permasalahan kesehatan gigi dan mulut

\begin{tabular}{ccccccc}
\hline Mahasiswa & \multicolumn{3}{c}{ Keluhan Permasalahan } & \multicolumn{2}{c}{ Total } \\
& \multicolumn{2}{c}{ Bermasalah } & \multicolumn{2}{c}{ Tidak Bermasalah } & & \\
& $\mathrm{n}$ & $\%$ & $\mathrm{n}$ & $\%$ & $\mathrm{n}$ & $\%$ \\
\hline Kesehatan & 188 & 43,7 & 27 & 6,3 & 215 & 50 \\
Non Kesehatan & 194 & 45,1 & 21 & 4,9 & 215 & 50 \\
Total & 382 & 88,8 & 48 & 11,2 & 430 & 100 \\
\hline
\end{tabular}


Tabel 3. Distribusi keluhan subyektif permasalahan kesehatan gigi dan mulut

\begin{tabular}{|c|c|c|c|c|c|c|}
\hline \multirow{3}{*}{$\begin{array}{c}\text { Keluhan } \\
\text { Permasalahan }\end{array}$} & \multicolumn{4}{|c|}{ Mahasiswa } & \multirow{2}{*}{\multicolumn{2}{|c|}{$\begin{array}{c}\text { Total } \\
(\mathrm{n}=\mathbf{3 8 2})\end{array}$}} \\
\hline & \multicolumn{2}{|c|}{$\begin{array}{l}\text { Kesehatan } \\
(n=188)\end{array}$} & \multicolumn{2}{|c|}{$\begin{array}{c}\text { Non Kesehatan } \\
\quad(n=194)\end{array}$} & & \\
\hline & $\mathrm{n}$ & $\%$ & $\mathrm{n}$ & $\%$ & $\mathrm{n}$ & $\%$ \\
\hline Karies & 68 & 36,2 & 93 & 47,9 & 161 & 42,1 \\
\hline Halitosis & 46 & 24,5 & 49 & 25,3 & 95 & 24,9 \\
\hline Gingivitis & 36 & 19,1 & 37 & 19 & 73 & 19,1 \\
\hline RAU & 106 & 56,4 & 98 & 50,5 & 204 & 53,4 \\
\hline Stain & 28 & 14,9 & 41 & 21,1 & 69 & 18 \\
\hline Hipersensitif dentin & 44 & 23,4 & 55 & 28,3 & 99 & 25,9 \\
\hline Kalkulus & 10 & 5,3 & 12 & 6,2 & 22 & 5,8 \\
\hline Keluhan gigi M3 & 14 & 7,4 & 14 & 7,2 & 28 & 7,3 \\
\hline Keluhan lain & 4 & 2,1 & 8 & 4,1 & 12 & 3,1 \\
\hline
\end{tabular}

Hasil uji korelasi chi-square mengenai hubungan pengetahuan dengan tindakan menjaga kesehatan gigi dan mulut mendapatkan nilai $\mathrm{p}=0,007(\mathrm{p}<0,05)$ yang menunjukkan terdapat hubungan bermakna antara pengetahuan dengan tindakan menjaga kesehatan gigi dan mulut.

Hasil uji chi-square terhadap hubungan pengetahuan kesehatan gigi dan mulut dengan keluhan subyektif permasalahan kesehatan gigi dan mulut memperoleh $\mathrm{p}=0,404$ ( $p>0.05$ ) yang berarti tingkat pengetahuan kesehatan gigi dan mulut tidak memiliki hubungan bermakna dengan keluhan subyektif permasalahan kesehatan gigi dan mulut. Hasil uji terhadap hubungan tindakan menjaga kesehatan gigi dan mulut dengan keluhan subyektif permasalahan kesehatan gigi dan mulut mendapatkan $\mathrm{p}=0,023$ $(\mathrm{p}<0,05)$, yang menunjukkan bahwa tindakan menjaga kesehatan gigi dan mulut memiliki hubungan bermakna dengan keluhan subyektif permasalahan kesehatan gigi dan mulut.

\section{BAHASAN}

Penelitian ini dilakukan terhadap 430 responden untuk mengetahui hubungan antara tingkat pengetahuan dan tindakan menjaga kesehatan gigi dan mulut dengan keluhan subyektif permasalahan kesehatan gigi dan mulut pada mahasiswa Universitas Diponegoro angkatan 2016-2019. Tingkat pengetahuan mahasiswa kesehatan dan non kesehatan tentang kesehatan gigi dan mulut umumnya tinggi dan tidak ada responden yang berada pada kategori tingkat pengetahuan rendah. Hal ini menunjukkan bahwa mahasiswa Undip memiliki kemampuan untuk memperoleh, memikirkan, dan memahami informasi yang didapatkannya mengenai kesehatan gigi dan mulut dengan baik. Pendidikan merupakan salah satu faktor yang memengaruhi pengetahuan, terutama pengetahuan kesehatan.

Pertanyaan pada kuesioner pengetahuan dengan jawaban salah terbanyak ialah pertanyaan mengenai cara membersihkan lidah. Lidah, salah satu organ yang berperan penting dalam fungsi pengunyahan, memiliki struktur permukaan yang berbeda dengan enamel gigi sehingga penggunaan pembersih lidah (seperti tongue scraper atau bagian belakang kepala sikat gigi) lebih direkomendasikan daripada menggunakan bulu sikat gigi. ${ }^{9}, 10$

Hasil dari tindakan menjaga kesehatan gigi dan mulut mahasiswa Undip umumnya berada dalam kategori sedang. Berdasarkan jawaban responden, tindakan berupa kunjungan dan pemeriksaan ke dokter gigi secara teratur serta penggunaan dental floss masih minim dilakukan. Hasil ini selaras dengan hasil Riskesdas 2018, yaitu sebanyak 95,5\% masyarakat Indonesia tidak pernah berobat ke dokter gigi, ${ }^{4}$ padahal 
pemeriksaan gigi secara rutin minimal 6 bulan sekali telah dihimbau oleh pemerintah serta Persatuan Dokter Gigi Indonesia (PDGI) untuk menjaga dan meningkatkan kesehatan gigi dan mulut masyarakat. Pemakaian dental floss secara rutin bersama dengan sikat gigi juga telah direkomendasikan untuk meningkatkan kebersihan gigi dan mulut. ${ }^{11}$

Penelitian yang dilakukan oleh Eni et $\mathrm{al}^{12}$ memaparkan bahwa tingkat pengetahuan dan perilaku oral hygiene mahasiswa kesehatan lebih tinggi dan lebih baik daripada mahasiswa non kesehatan. Hal tersebut sesuai dengan hasil penelitian ini yang menunjukkan bahwa tingkat pengetahuan dan tindakan menjaga kesehatan gigi dan mulut mahasiswa kesehatan lebih baik daripada mahasiswa non kesehatan. Mahasiswa kesehatan dipersiapkan untuk menjadi tenaga kesehatan professional di masa depan, sehingga pengetahuan dan tindakan menjaga kesehatan gigi dan mulut kesehatan pada mahasiswa kesehatan diharapkan lebih baik daripada mahasiswa non kesehatan. Hal ini berkaitan dengan kebutuhan mahasiswa kesehatan dalam melakukan edukasi kepada pasien dan komunitas saat mereka mulai bekerja.

Sebagian besar responden penelitian ini memiliki keluhan RAU yaitu keadaan nyeri pada mukosa rongga mulut yang muncul berulang dan terdapat dalam berbagai tipe serta lebih sering ditemukan pada dekade kedua atau usia 20 tahunan. ${ }^{13}$ Selain RAU, karies gigi juga merupakan permasalahan yang banyak dikeluhkan oleh responden penelitian ini. Hasil ini didukung oleh hasil Riskesdas 2018 yang memperlihatkan tingginya prevalensi permasalahan karies gigi di Indonesia yakni mencapai angka $88,8 \% .^{4}$ Permasalahan gigi dan mulut dapat memengaruhi aktivitas dan kualitas hidup seseorang sehingga dibutuhkan penanganan segera oleh tenaga professional untuk mengatasinya.

Tingkat pengetahuan mahasiswa yang mayoritas berada pada kategori tinggi tidak diikuti dengan kondisi terbebasnya keluhan terkait permasalahan kesehatan gigi dan mulut. Tidak terdapatnya hubungan ber- makna antara tingkat pengetahuan dengan keluhan subketif permasalahan terkait kesehatan gigi dan mulut dapat disebabkan oleh berbagai faktor. Hasil penelitian ini berbanding terbalik dengan penelitian oleh Astini et $a^{14}$ yang memaparkan bahwa terdapat hubungan bermakna antara pengetahuan dan perilaku menjaga kesehatan gigi dengan oral hygiene. Meskipun pengetahuan merupakan domain yang memiliki kontribusi besar dalam membentuk derajat kesehatan gigi dan mulut, namun pengetahuan saja tidak cukup. Sikap dan tindakan yang mendukung juga diperlukan dalam memengaruhi derajat kesehatan gigi dan mulut. Hal ini dapat didukung oleh teori menurut Henrik L. Blum yang menyatakan bahwa pengetahuan hanya merupakan salah satu faktor yang memengaruhi perilaku, sedangkan status kesehatan individu atau masyarakat dipengaruhi oleh empat faktor, yaitu: lingkungan, perilaku, pelayanan kesehatan, dan keturunan. ${ }^{15}$

Pada penelitian ini ditemukan bahwa tindakan menjaga kesehatan gigi dan mulut merupakan faktor penting yang mendukung keluhan subyektif permasalahan kesehatan gigi dan mulut. Hasil penelitian ini selaras dengan penelitian oleh Panjaitan et $\mathrm{al}^{16}$ yang menyatakan adanya hubungan bermakna antara perilaku kesehatan gigi dan mulut dengan permasalahan gigi berlubang (indeks DMF-T). Menurut Laurence Green, perilaku seseorang dapat dipengaruhi oleh tiga faktor, yakni: faktor predisposisi, faktor pendukung, dan faktor penguat. Faktor predisposisi meliputi kepercayaan, sikap, dan pengetahuan. Faktor pendukung meliputi sarana atau fasilitas, seperti obatobatan, peralatan, dan fasilitas kesehatan. Faktor penguat meliputi sikap dan perilaku tenaga kesehatan atau tenaga kerja lainnya. ${ }^{6}$

Perbedaan hasil penelitian ini dengan penelitian yang telah dilakukan sebelumnya ialah hanya terdapat salah satu variabel bebas yang memiliki hubungan bermakna dengan keluhan subyektif permasalahan gigi dan mulut, yakni tindakan menjaga kesehatan gigi dan mulut. Hal ini kemungkinan dapat disebabkan karena mahasiswa memiliki pengetahuan mengenai kesehatan gigi 
dan mulut yang luas sehingga mereka tahu cara menjaga kesehatan gigi dan mulut namun belum merealisasikannya ke dalam tindakan sehari-hari. Selain itu, rentang usia responden yang berdekatan juga dapat menjadi salah satu kemungkinan hasil tersebut.

Keterbatasan jumlah mahasiswa yang bersedia menjadi responden penelitian serta jumlah sampel minimal yang diperlukan menyebabkan penelitian ini tidak dapat menganalisis hubungan antara pengetahuan dan tindakan menjaga kesehatan gigi dan mulut dengan keluhan permasalahan gigi dan mulut berdasarkan jenis kelamin dan angkatan. Selain itu, keadaan pandemi COVID-19 yang tejadi saat penelitian menyebabkan penilaian permasalahan masingmasing responden tidak dapat dilakukan secara langsung.

Diperlukan penelitian lanjut yang lebih meluas untuk memperoleh gambaran yang lebih mewakili karakteristik asli dari populasi yang sedang diteliti, mem-pertimbangkan faktor lain yang tidak diteliti dalam penelitian ini, seperti indeks DMF-T, OHIS, dan lainnya sehingga penilaian dapat dilakukan lebih objektif, serta menggunakan jumlah sampel berdasarkan jenis kelamin dan angkatan dengan rasio yang sama besar. Untuk mahasiswa kesehatan dan non kesehatan diharapkan dapat meningkatkan kesadaran akan kesehatan gigi dan mulut sebagai tindakan preventif sebelum terjadi permasalahan gigi dan mulut, seperti kunjungan rutin ke dokter gigi setiap 6 bulan sekali.

\section{SIMPULAN}

Terdapat hubungan bermakna antara tindakan menjaga kesehatan gigi dan mulut dengan keluhan subyektif permasalahan kesehatan gigi dan mulut namun tidak terdapat hubungan antara tingkat pengetahuan kesehatan gigi dan mulut dengan keluhan subyektif permasalahan gigi dan mulut. Tingkat pengetahuan dan tindakan menjaga kesehatan gigi dan mulut mahasiswa kesehatan lebih baik daripada mahasiswa non kesehatan.

\section{Konflik Kepentingan}

Penulis menyatakan tidak terdapat konflik kepentingan dalam studi ini

\section{DAFTAR PUSTAKA}

1. Jain M, Bharadwaj SP, Kaira LS, Chopra D, Prabu D, Kulkarni S. Oral health status and treatment need among institutionalised hearing-impaired and blind children and young adults in Udaipur, India. A comparative study. OHDM Journal. 2013;12(1):41-9.

2. Wihardja R, Setiadhi R. Kondisi kesehatan gigi dan mulut siswa SDK Yahya. J Ked Gi Unpad. 2018;30(1):26-32. Doi: https:// doi.org/ 10.24198/jkg.v30i1.16247

3. Tjahja IN, Lely MA. Hubungan kebersihan gigi dan mulut dengan pengetahuan dan sikap responden di beberapa puskesmas di propinsi Jawa Barat. Media Litbang Kesehatan. 2005;15(4):1-7.

4. Kementerian Kesehatan RI. Laporan Nasional RISKESDAS 2018. Jakarta: Kementerian Kesehatan RI, 2018; p. 184-204.

5. Suwelo IS. Karies Gigi pada Anak dengan Pelbagai Faktor Etiologi. Jakarta: EGC, 1992.

6. Notoatmodjo S. Promosi Kesehatan dan Perilaku Kesehatan. Jakarta: Rineka Cipta, 2014; p. 131-43.

7. Budiharto. Pengantar Ilmu Perilaku Kesehatan dan Pendidikan Kesehatan Gigi. Jakarta: EGC, 2010; p. 17-21.

8. Rahayu C, Widiati S, Widyanti N. Hubungan antara pengetahuan, sikap, dan perilaku terhadap pemeliharaan kebersihan gigi dan mulut dengan status kesehatan periodontal pra lansia di posbindu Kecamatan Indihiang Kota Tasikmalaya. Maj Ked Gi. 2014;2(1):27-32. Doi: https://doi.org/10.22146/majked giind. 8515

9. Kumbargere NS, Eachempati P, Uma E, Singh $\mathrm{VP}$, Ismail NM, Varghese E. Interventions for managing halitosis. Cochrane Database of Systematic Reviews. 2019;12:1-109. Doi: https:// doi.org/10.1002\%2F14651858.CD012 213.pub2

10. Dwivedi V, Torwane NA, Tyagi S, Maran S. Effectiveness of various tongue cleaning aids in the reduction of tongue coating and bacterial load: a comparative clinical study. J Contemp Dent Pract. 2019;20(4):444-8. Doi: 10.5005/jpjournals-10024-2536

11. Marlindayanti, Ningrum N, Manurung NK. 
78 e-GiGi, Volume 9 Nomor 1, Januari-Juni 2021, hlm. 71-78

Pelayanan Asuhan Kesehatan Gigi dan Mulut Masyarakat. Jakarta: Kementerian Kesehatan RI, 2018; p. 5-288.

12. Eni MLF, Kusumadewi S, Sari KAK. Gambaran perilaku berdasarkan sosiodemografi, pengetahuan, persepsi terkait oral hygiene pada mahasiswa kesehatan dan non kesehatan Universitas Udayana. Odonto Dental Journal. 2018; 5(1):18-27. Doi: http://dx.doi.org/10. 30659/odj.5.1.18-27

13. Gianetti L, Murri DDA, Lo Muzio L. Reccurent aphtous stomatitis. Minerva Stomatol. 2018;67(3):125-8. Doi: https: //doi.org/10.23736/S0026-4970.18. 04137-7

14. Astini NWRS, Susanti DNA, Handoko SA.
Hubungan antara pengetahuan dan perilaku kesehatan gigi dengan oral hygiene pada mahasiswa Program Studi Pendidikan Dokter Gigi Fakultas Kedokteran Universitas Udayana. BDJ. 2019;3(2):70-3. Doi: https://doi.org/ 10.37466/bdj.v3i2.167

15. Eliana, Sumiati S. Kesehatan Masyarakat. Jakarta: Kementerian Kesehatan RI, 2016; p. 21-3.

16. Panjaitan M, Anastasia I, Novelina. Hubungan pengetahuan, sikap dan perilaku kesehatan gigi dan mulut terhadap indeks DMF-T pada siswa kelas XII di SMA Y.P Antasari Deli Serdang. Prima JODS. 2018;1(1):32-40. 